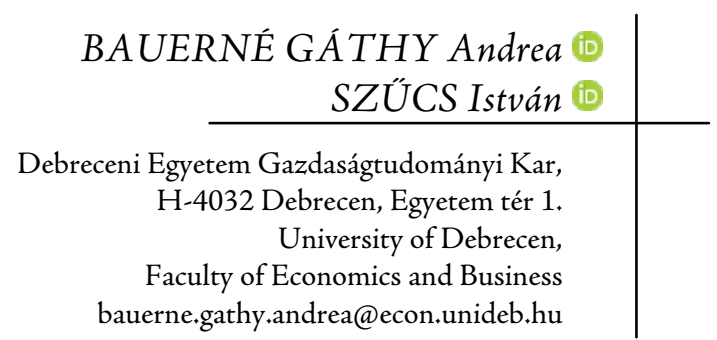

\section{FENNTARTHATÓ ÉLELMISZER-FOGYASZTÁS A DEBRECENI EGYETEM HALLGATÓINAK KÖRÉBEN}

\author{
SUSTAINABLE FOOD CONSUMPTION ATTITUDES \\ AMONG THE STUDENTS OF THE \\ UNIVERSITY OF DEBRECEN
}

\begin{abstract}
As the public interest in sustainability increases, the challenge of the next decades is how we can handle the growing food demand. The global food supply has never been so complex, and the growth of the global population will reorganise it. The food consumer behaviour determines the consumer behaviour from the point of view of sustainability. This study aims to contribute to the debate on university students' food buying practices with regard to sustainability issues. The empirical research builds on a questionnaire survey with a sample of 500 young consumers, students of the University of Debrecen. The primary purpose of the study is to survey the daily eating habits of the students of Debrecen, to analyse what kind of special and individual diet they follow. We will analyse what is the reason for a special diet: some kind of disease or an individual decision. We will compare the food consumer behaviour of the students with the special diets (Vegetarian, Vegan, Paleo, etc.) with the mixed diet from the aspect of sustainability.
\end{abstract}

Kulcsszavak: élelmiszer-fogyasztás, egészségtudatosság, környezettudatosság, fenntarthatóság, egyetemi hallgatók Keywords: food consumption, health-consciousness, eco-consciousness, sustainability, university students

JEL-kód: C38, D70, I12, M31, Q56

\section{BEVEZETÉS}

A fenntartható fogyasztást egyszerre jellemzi az egészségtudatosság és a környezettudatosság, ami olyan termékek és szolgáltatások megvásárlásában és elfogyasztásában nyilvánul meg, amelyek megfelelnek a legalapvetőbb igényeknek, és jobb életminőséget eredményeznek, miközben minimalizálják a természeti erőforrások és a természetet károsító anyagok használatát, a hulladék- és szennyezőanyag-kibocsátást egész életciklusok során. Különösen hangsúlyos ez a megközelítés az élelmiszer-fogyasztást tekintve, hiszen annak környezetterhelő hatása mind az input mind az output oldalon jelentős.

A fenntartható és környezettudatos élelmiszer-fogyasztás alapelvei között említhetjük a növényi eredetü élelmiszerek, zsiradékok előnyben részesítését az állati eredetűekkel szemben, a kevésbé feldolgozott, inkább regionális élelmiszerek fogyasztását, az állati eredetű fehérjefogyasztás visszaszorítását. Az egészséges és a környezettudatos táplálkozás követelményei sok esetben összecsengenek, több kutatás megállapította már, hogy azok az ételek, amelyeknek a fogyasztását egészségügyileg káros hatásuk miatt csökkenteni kellene, áltatában a magasabb környezetterheléssel is járó élelmiszerek (Alsaffar, 2016; Ruini et al., 2015;
Macdiarmid et al., 2016). Az élelmiszer-fogyasztáshoz társuló negatív környezeti hatások föként a területhasználat, az energiaigény és a vízigény esetében jelentősek. Kiss és szerzőtársai szakirodalmi áttekintésükkel is alátámasztják, hogy az élelmiszer-fogyasztás, az egészség és a környezet kérdéseit egymással összefüggésben célszerű vizsgálni, s nagyobb hangsúlyt kell adni a környezeti aspektusnak (Kiss et al., 2019).

A fenntartható fogyasztást feltételezésünk szerint egyszerre jellemzi az egészségtudatosság és a környezettudatosság, ennek a kapcsolatnak a vizsgálata a központi eleme jelen tanulmánynak. Elöször azonban a fogalmi háttér tömör áttekintésére kerül sor, fontos ugyanis tisztázni, hogy mit értünk a tudatos fogyasztás, a tudatos élelmiszer-fogyasztás, egészségtudatos fogyasztói magatartás és környezettudatos fogyasztói magatartás alatt. Ezt követően egy a Debreceni Egyetem (DE) hallgatói körében elvégzett 500 fös kérdőíves megkérdezés eredményei alapján vonunk le következtetéseket az egészségtudatosság és környezettudatosság öszszefüggéseire vonatkozóan az élelmiszer-fogyasztás tekintetében.

A hazai és a nemzetközi szakirodalomra támaszkodva az a fogyasztó tekinthető tudatos fogyasztónak, aki a vásárlásai alkalmával, illetve szolgáltatások igénybevételénél körültekintően választ, ismeri azokat az információkat, amelyek által tájékozódhat a ter- 
mék tulajdonságairól, valamint saját érdekeire és mások érdekeire is tekintettel van (Lehota et al., 2018; Tudatos Vásárlók Egyesülete, 2017; Totth, 2018; Töröcsik, 2003; Brochado et al., 2016; Zabkar E Hosta, 2013).

A tudatos fogyasztás kialakulása összetett folyamat és több motívummal jellemezhető. Elsőként a fogyasztóban meg kell, hogy jelenjen az igény arra, hogy ne csak passzív „bevásárló”, hanem tudatos, elöre tervező, a saját szükségleteivel és céljaival tisztában lévő fogyasztó legyen. Ennek érdekében meg kell ismernie a termékeket és szolgáltatásokat, vagy a vásárlás során vagy még inkább azt megelőzően informálódnia kell ezekről. Ezt követően meg kell figyelnie azt, hogy a fogyasztási cikkek hogyan helyezkednek el a piacon, majd elengedhetetlen, hogy tisztában legyen a többek között fogyasztói jogokra vonatkozó információkkal. Külön ismernie kell, hogy mint fogyasztó hogyan hat a környezetére, különös tekintettel a fenntarthatóságra (Ádám, 2001).

A marketing-szakirodalomban is nagyon színesnek tekinthető a "tudatosság” fogalma, bár egységes definíciót nem találunk arra, hogy pontosan mit értenek tudatos fogyasztás, tudatos vásárlás alatt. Dudás (2012) megfogalmazása alapján a tudatos fogyasztó legáltalánosabban a következőképpen határozható meg: az a fogyasztó, aki tudatában van fogyasztói jogainak és azok érvényesítési lehetőségeinek; alapos információkereső és -igénylő magatartás jellemzi; márka, ár és/vagy minőség alapján tudatosan - tehát előzetes koncepciók alapján, mélyreható informálódást és alapos megfontolást követően - hozza meg vásárlási döntéseit; vannak már felismert önérdekei (pl. egészségtudatosság), ami alapján döntéseket hoz; önérdekein túl hajlandó figyelembe venni mások érdekeit is (pl. környezeti, társadalmi és gazdasági szempontból). A fentiek közül nem jellemez minden tudatos fogyasztót minden kritérium, de már egy, a fentiekben tárgyalt jellemző megléte is ebbe a csoportba sorolja őt.
Dudás (2012) szerint három részterület rajzolódik ki (1. ábra): az önérdekre fókuszáló tudatosság területe, a mások érdekeit szem előtt tartó tudatosság szférája (itt jelenik meg a környezettudatosság és a fenntartható fogyasztás is az idézett szerző olvasatában) és az ún. köztes szféra, ahol az országeredet-tudatosság és a pénzügyi tudatosság szerepel. Az országeredet- és a pénzügyi tudatosság egyaránt jelentős szerepet játszik az önérdek és a közösségi érdek kapcsán is. A kutatás során szekunder és primer információt gyüjtöttünk és elemeztünk. Elsőként a téma hátteréül szolgáló hazai és nemzetközi szakirodalmat tekintettük át abból a célból, hogy a témához kapcsolódó fogalmak definiálásra kerüljenek, képet kapjunk a témával kapcsolatos kutatások eredményeiről. A bevezető részben ennek egy tömör kivonatát jelenítettük meg a tanulmány központi témájára koncentrálva.

A kvantitatív (mennyiségi) kutatás lépéseként kérdőives megkérdezést végeztük el a Debreceni Egyetem hallgatói körében 2019 áprilisa és júliusa között. Egyaránt alkalmaztuk az online kérdőíves felmérés és az offline mintavételi módszert (személyes, papíralapú megkérdezést), mely során kvóta szerinti mintavételezéssel kiemelt figyelmet fordítottunk arra, hogy a hallgatók eltérő ismeretekkel rendelkezzenek az egészségtudatos táplálkozás és a környezettudatos élelmiszer-fogyasztás témakörében. A vizsgálat jelen esetben a felnövő generáció élelmiszer-fogyasztási szokásainak felmérésére irányult, amelyet az alábbiakkal indokolhatjuk: a mostani 18-25 éves korosztály tekinthető a „közeljövő fogyasztójának”; a vizsgált korcsoportban a felsőoktatási hallgatók esetében elmondható, hogy a fogyasztásaik során, különösen az élelmiszer-fogyasztás területén önálló döntéshozónak tekinthetőek; az ebben az időszakban kialakult fogyasztási minták - melyet az oktatásból szerzett információk is befolyásolnak - meghatározóak lehetnek a későbbiekre is.

1. ábra: A tudatos fogyasztás területei

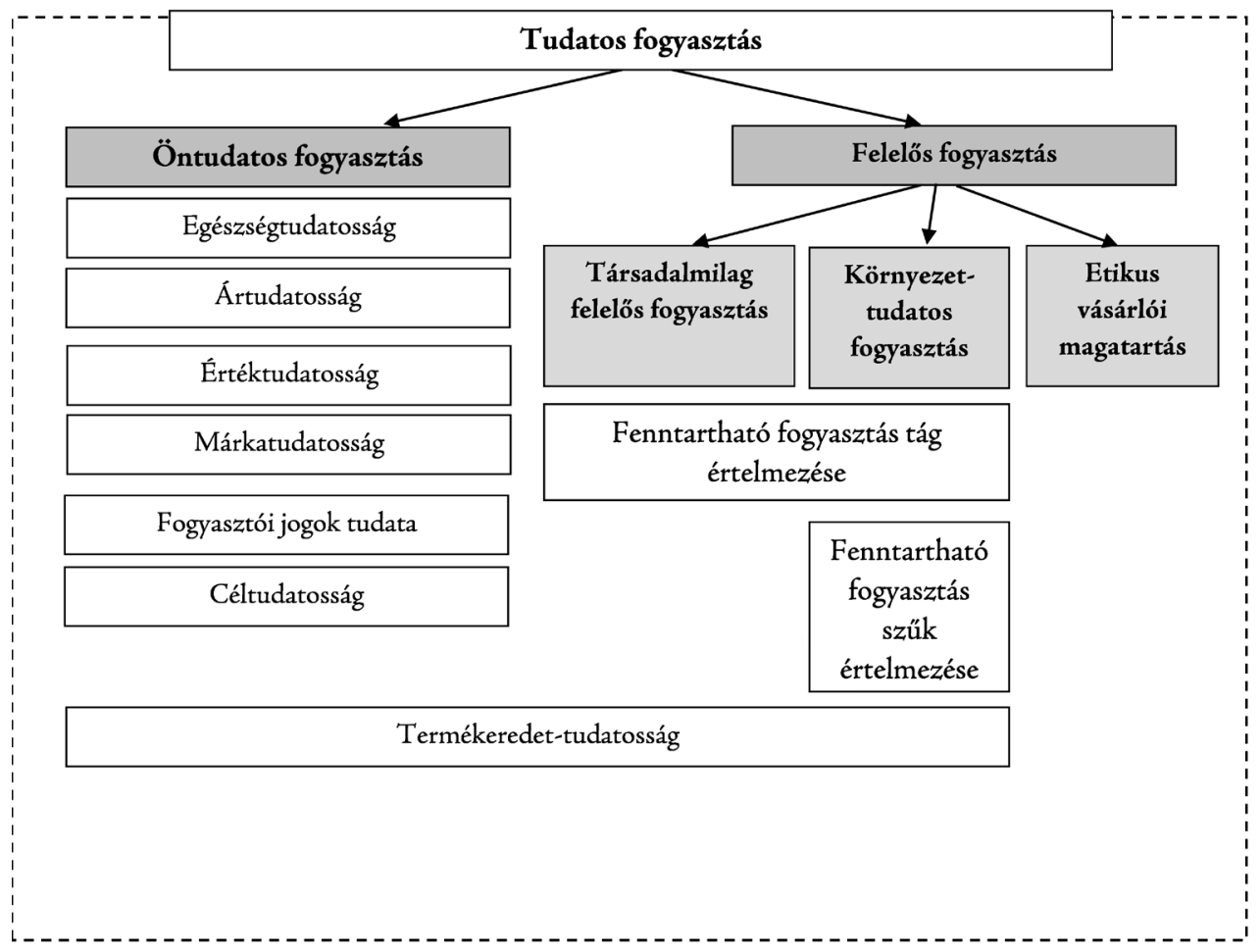

Forrás: Dudás, 2012 
Dudás (2010) korábbi megközelítéséhez képest ezzel kiemelésre került a pénzügyi tudatosság az önérdek kategóriából, hiszen a vásárlási döntéseivel a fogyasztó szavaz abból a szempontból is, hogy az általa elköltött pénzmennyiség mely nemzetet gazdagítja, így a fogyasztási döntései már túlmutatnak az önérdekein.

Amennyiben ezt a felosztást elfogadjuk, érdekes azt vizsgálni, hogy melyik jellemzi inkább a fogyasztókat, az önérdek követése vagy a mások érdekeit is figyelembe vevő döntéshozatal. Jelen tanulmány egy része arra fókuszál majd, hogy a felmérésben résztvevők esetében melyik a jellemzőbb.

Több szerző is kiemeli, hogy az egészség nagyon jó hívószónak tekinthető, így az önérdek felől indítva motiválhatóak jobban a fogyasztók a környezetbarát termékek vásárlására (Dudás, 2012; Szakály et al., 2014; Töröcsik, 2014; De Boer E Aiking, 2018.) Kutatásunkban az egészségtudatosság és a környezettudatosság összefüggéseit elemezzük, kísérletet téve arra is, hogy meghatározzuk, mely tudatosság jelenik meg dominánsabban a válaszadóknál.

Itt kell megjegyeznünk, hogy a vélt és a valós tudatosság közötti összefüggés is fontos kérdés. Sok esetben találkozhatunk azzal, különösen a kérdőíves felmérések során, hogy a válaszadó sokkal pozitívabb képet fest magáról, mint ami a valóságban jellemzi. Ez a viselkedésforma úgy véljük, hogy nem feltétlenül tudatos félrevezetés, visszavezethető arra is, hogy a fogyasztó saját magáról alkotott, akár idealizált képe a fogyasztási választásai során már nem alakulnak át tudatos döntéssé, $\mathrm{s}$ a valóságban nem befolyásolják a fogyasztási döntéseit. Szűcs kis mintás felméréseire alapozva állítja, hogy a kutatási területtől függően a fogyasztók csupán 10-20\%a mutatott fel valódi tudással alátámasztható, elfogadható szintü tényleges tudatosságot (Szücs, 2019). A valódi és a vélt tudatosság közötti eltérés már egy kevésbé vizsgált területnek tekinthető, azonban annál inkább jelentős, hiszen a valós tetteink gyakorolhatják a negatív hatást mind a saját mind a környezetünk állapotára. A kutatás során törekedtünk arra, hogy elkülönítsük a vélt és a valós tudatosságot, mind az egészségtudatosság mind a környezettudatosság tekintetében, és ezt követően elemezzük, hogy mely tényező jelenik meg erőteljesebben, és melynek van nagyobb hatása a fogyasztói döntésekre az élelmiszer-fogyasztás területén.

\section{ANYAG ÉS MÓDSZER}

A kutatás során szekunder és primer információt gyüjtöttünk és elemeztünk. Elsőként a téma hátteréül szolgáló hazai és nemzetközi szakirodalmat tekintettük át abból a célból, hogy a témához kapcsolódó fogalmak definiálásra kerüljenek, képet kapjunk a témával kapcsolatos kutatások eredményeiről. A bevezető részben ennek egy tömör kivonatát jelenítettük meg a tanulmány központi témájára koncentrálva.

A kvantitatív (mennyiségi) kutatás lépéseként kérdőíves megkérdezést végeztük el a Debreceni Egyetem hallgatói körében 2019 áprilisa és júliusa között. Egyaránt alkalmaztuk az on-line kérdőíves felmérés és az offline mintavételi módszert (személyes, papíralapú megkérdezést), mely során kvóta szerinti mintavételezéssel kiemelt figyelmet fordítottunk arra, hogy a hallgatók eltérő ismeretekkel rendelkezzenek az egészségtudatos táplálkozás és a környezettudatos élelmiszer-fogyasztás témakörében. A vizsgálat jelen esetben a felnövő generáció élelmiszer-fogyasztási szokásainak felmérésére irányult, amelyet az alábbiakkal indokolhatjuk: a mostani 18-25 éves korosztály tekinthető a „közeljövő fogyasztójának"; a vizsgált korcsoportban a felsőoktatási hallgatók esetében elmondható, hogy a fogyasztásaik során, különösen az élelmiszer-fogyasztás területén önálló döntéshozónak tekinthetőek; az ebben az időszakban kialakult fogyasztási minták - melyet az oktatásból szerzett információk is befolyásolnak - meghatározóak lehetnek a későbbiekre is.

A minta nagysága az adattisztítás és a minta nem szerinti reprezentativitásának kialakítása után 500 fós $(\mathrm{n}=500)$ volt, melyben a hallgatók karok szerinti számának megoszlása és azon belül is a nemek megoszlása tükrözi a Debreceni Egyetem oktatási hivatala által kiadott létszámadatokat. A felmérésben a részvétel önkéntes volt, azonban a karok hallgatói létszáma és a nemi reprezentativitás biztosítása érdekében kvótás mintavételt alkalmaztunk. 2019. március 15-i adatok alapján 24480 fó volt az egyetem hallgatója, mely egyaránt tartalmazza az összes nappali, levelező, PhD-képzés és szakirányú továbbképzés hallgatóinak számát a 14 kar eseté-ben. Kutatásunk feltáró jellegéből adódóan a Debreceni Egyetem hallgatóinak homogén csoportját vizsgálva azonban eredményeinkből levont következtetések csak a Debreceni Egyetem hallgatóinak élelmiszer-fogyasztási szokásaira, attitüdjeire vonatkoznak, viszont jellemzőek lehetnek más felsőoktatásban résztvevő hallgatók esetében is.

A kérdőív háttérváltozói között szerepelt a nemre, a korra, az iskolai végzettségre, a szubjektív jövedelemérzetre, a felsőoktatásban való részvétel formájára és szintjére, a testtömegindex meghatározásához szükséges testtömegre és magasságra vonatkozó kérdés.

\subsection{A minta bemutatása}

A felmérésben az adattisztítás és a minta nem szerinti reprezentativitásának kialakítása után 500 fö $(\mathrm{n}=500)$ által kitöltött kérdőív került kiértékelésre. A válaszadók mindegyike a Debre-ceni Egyetemen (DE) aktív hallgatói jogviszonnyal rendelkező személy, képzési formát tekintve 82,4\%-uk nappali és 17,6\%-uk levelező hallgató. A megkérdezettek nemek szerinti megoszlása tükrözi a teljes sokaság arányait, 219 férfi (43,8\%) és 281 (56,2\%) nő volt. Lakóhely tekintetében a megyeszékhely a legjellemzőbb $(45,2 \%)$. A szubjektív jövedelmi helyzetet tekintve a megkérdezettek többsége a magasabb jövedelmi helyzetű (37\%-ban a „Megélnek a jövedelmükből és tudnak félretenni” és 29\%-ban a "Jól megélnek a jövedelmükből és tudnak félretenni” választ jelölték meg) kategóriába sorolható, de itt kiemelendő, hogy a család (tehát nem önálló) jövedelmi helyzetről nyilatkoztak, mivel aktív egyetemi hallgatókat kérdeztünk meg.

A 2. ábra bemutatja a megkérdezettek karok szerinti megoszlását, mely esetben szintén elmondható, hogy a minta megfelel a sokaság arányainak. A Debreceni Egyetem öt legnagyobb hallgatói létszámmal rendelkező kara az ÁOK (3.467 fö), a GTK (3.334 fö), a BTK (2.524 fö), az MK (2.495 fö) és a TTK (2.487 fö). 
2. ábra: A minta kar szerinti megoszlása a Debreceni Egyetem esetében $(\mathbf{n}=500)$

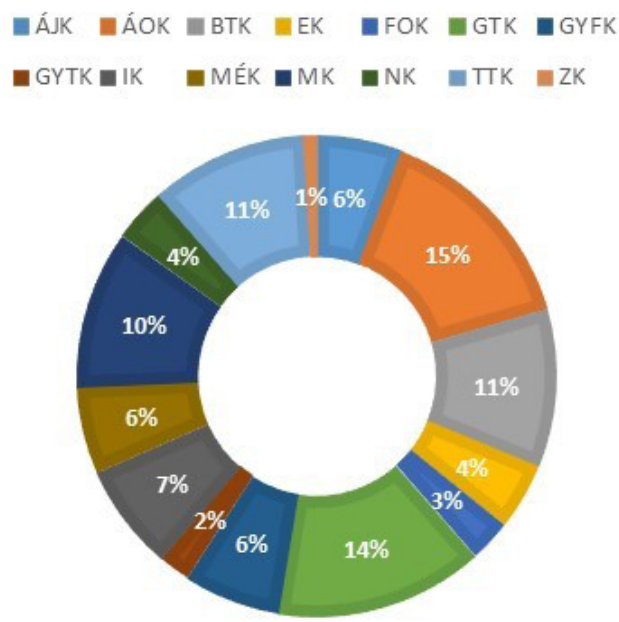

\footnotetext{
Megjegyzés: ÁJK - Állam és Jogtudományi Kar, ÁOK - Általános Orvostudományi Kar, BTK - Bölcsészettudományi Kar, EK - Egészségügyi Kar, FOK - Fogorvostudományi Kar, GTK - Gazdaságtudományi Kar, GYFK - Gyermeknevelési-és Gyógypedagógiai Kar, GYTK - Gyógyszerésztudományi Kar, IK - Informatikai Kar, MÉK - Mezögazdaság-, Élel-miszertudományi és Környezetgazdálkodási Kar, MK - Müszaki Kar, NK - Népegészségügyi Kar, TTK - Természettudományi és Technológiai Kar, ZK - Zenemü-vészeti Kar
}

\subsection{A Kérdőív jellemzői}

A kérdőiv összeállításánál egyaránt alkalmaztunk zárt és nyílt kérdéseket, mely által arra törekedtünk, hogy mérvadó információ legyen begyüjthető a vizsgálat tárgyát illetően. Ezek mellett a kérdőív központi része a különböző élelmiszerek (a táplálkozási piramis élelmiszerkategóriák alapján) fogyasztási gyakoriságát méri, ahol a gyakoriságot tekintve egy hétfokozatú intervallumskálát alkalmaztunk, ahol a "soha” és a "naponta” történo” fogyasztás jelentette az intervallum két szélső értékét. Külön kitértünk a fóétkezések közötti étkezésekre, annak helyére, valamint gyakoriságára étel és ital tekintetében egyaránt. Továbbá az élelmiszer-fogyasztással és annak körülményivel kapcsolatos állításokat adtunk meg, melyeket a válaszadók egy ötfokozatú Likert-skála alapján értékelték ( $1=$ egyáltalán nem ért egyet, az $5=$ teljes mértékben egyetért).

\subsection{Adatelemzés}

A kérdôives kutatás során kapott adatokat matematikai-statisztikai analitikai (SPSS 23.0) szoftverrel dolgoztuk fel. Az adatrögzítést közvetlenül az adattisztítás folyamata után, a kérdőíves megkérdezés és az adatbevitel során keletkezett hibák, az outlierek kiszűrésére és az adatok feldolgozásához alapfokú leíró statisztikai módszereket alkalmaztunk (minimum, maximum, átlag, szórás, megoszlás, ferdeség). Az elemzés során az egyes változók közötti kapcsolatrendszer feltárása érdekében kereszttábla-elemzést is alkalmaztunk. A vizsgált változók közötti szignifikáns kapcsolat bizonyítására (vagy elvetésére) a Pearson-féle Chi2 próbát alkalmaztuk, az eredmények értelmezését $\mathrm{p}<0,05$ szint alatt végeztük. (Sajtos \& Mitev, 2007; Lázár, 2009).

\section{EREDMÉNYEK ÉS ÉRTÉKELÉSÜK}

A kutatás eredményeinek bemutatása előtt a minta jellegzetességeit foglaljuk össze, majd az előzőekben felvetett kérdéskörök mentén tárgyaljuk a felmérésből származó eredményeket.

A kutatás eredményei közül jelen tanulmányban a bevezetőben felvezetett témakörök, a tudatos fogyasztói magatartás, az egészségtudatos és/vagy környezettudatos élelmiszerfogyasztói sajátosságok és azok összefüggései kerülnek elemzésre és bemutatásra. Elsőként a tudatosságra kérdeztünk rá több szempont szerint: a válaszadóknak egy 5-ös skálán kellett értékelniük, hogy a felvetett kritériumok szerint milyen mértékben tartják magukat tudatos fogyasztónak (1. táblázat). A válaszadók esetében az ár tekintetében kaptuk a legmagasabb $(4,002)$ átlagértéket (a vizsgált korosztály is árérzékeny élelmiszer-fogyasztónak tekinthető) s ennél a kritériumnál volt a legkisebb a szórás is, ezt követi egy kis lemaradással a minőség mint szempont az élelmiszer-vásárlás és -fogyasztás tekintetében. A helyi termékek kapták a legalacsonyabb átlagértéket $(3,092)$, itt a medián is alacsonyabb (3) szinten van. 
1. táblázat: Az élelmiszer-fogyasztást befolyásoló tényezők megítélése a DE hallgatóinak körében $(\mathrm{n}=500)$

\begin{tabular}{|l|c|c|c|c|c|c|}
\hline & Ár & Minöség & Helyi termékek & Márka & Környezettudatosság & Egészségtudatosság \\
\hline Átlag & $\mathbf{4 , 0 0 2}$ & 3,916 & 3,092 & 3,112 & 3,296 & 3,644 \\
\hline Szórás & $\mathbf{0 , 8 9 2}$ & $\mathbf{1 , 0 3 9}$ & $\mathbf{1 , 2 3 4}$ & $\mathbf{1 , 1 4 1}$ & $\mathbf{1 , 0 4 6}$ & $\mathbf{1 , 0 1 9}$ \\
\hline Medián & $\mathbf{4}$ & 4 & 3 & 3 & 3 & 4 \\
\hline
\end{tabular}

Az 1. táblázat a kérdőív következő kérdésére adott válaszainak feldolgozásával készült: 1. kérdés: „Tudatos fogyasztónak vallja-e magát?" (1-egyáltalán nem vallom magam annak, 5 - teljes mértékben annak vallom magam, 0 - nem tudom eldönteni). A felsorolt kritériumok az ár, a minőség, a hazai termék, a márka, a környezettudatosság és az egészségtudatosság voltak.

Szintén ennél a kérdésnél látható, hogy a megkérdezettek nagyobb arányban tartják magukat tudatos élelmiszer-fogyasztónak az egészségtudatosság, mint a környezettudatosság szempontjából (3. ábra).
A megkérdezettek nagy többsége (72\%-a) csak részben tekinti magát egészségtudatos élelmiszer-fogyasztónak, a nem válaszok aránya $9 \%$, míg az igeneké $18 \%$ volt (4. ábra).

A kérdőív 3, „Környezettudatos fogyasztónak tartja-e magát?” kérdése esetében az egészségtudatossághoz képest kétszer annyian (18\%) jelölték be a nem választ és azt is, hogy nem is tudják, hogy az adott fogalom mit jelent (2\%) (5.ábra).

3. ábra: Az élelmiszer-fogyasztást befolyásoló tényezők értékelése a DE hallgatóinak körében $(\mathrm{n}=500)$

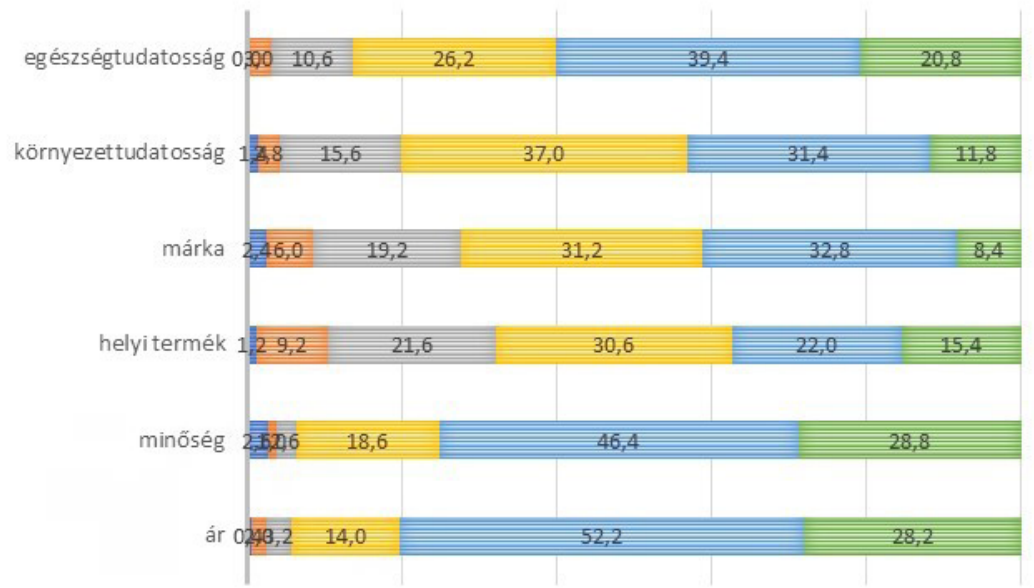

Megjegyzés: „Mennyire tartja tudatosnak magát a felsorolt tényezök szerint?” (szélsőértékek: egyáltalán nem - teljes mértékben)

4. ábra: Az egészségtudatosság megítélése a DE hallgatóinak körében $(\mathbf{n}=500)$

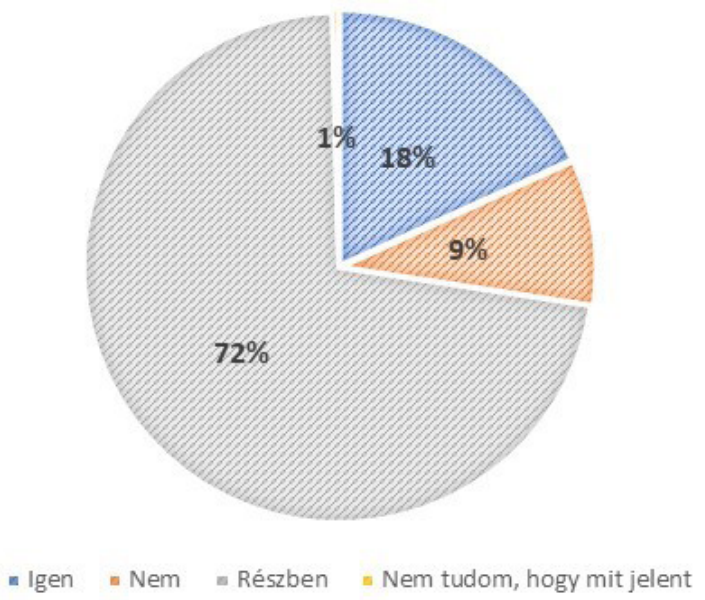

Megjegyzés: A 4. ábra a kérdőív 2. „Egészségtudatos fogyasztónak tartja-e magát?” kérdésére adott válaszok feldolgozása alapján készült. 
5. ábra: A környezettudatosság megítélése a DE hallgatóinak körében $(\mathrm{N}=500)$

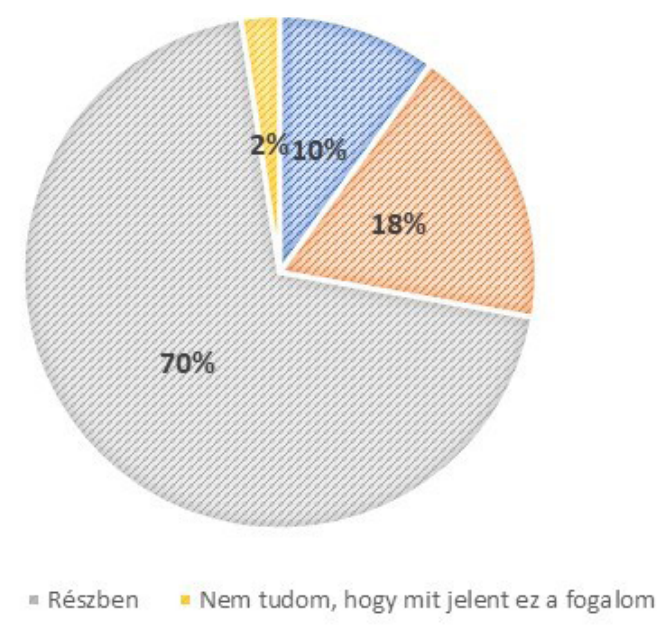

A fentiek alapján megállapítható, hogy a Debreceni Egyetem hallgatói kevésbé ismerik a környezettudatosság kritériumait, mint az egészségtudatosság jellemzőit, inkább tekintik magukat egészségtudatos élelmiszer-fogyasztónak, mint környezettudatos élelmiszer-fogyasztónak, s nagyobb arányban utasítják el az élelmiszer-fogyasztás kapcsán a környezeti szempontokat, inkább az önérdek dominál a mások érdekeivel szemben a döntéseiknél. Kiemelendő, hogy a fentiek minden esetben a vélt, saját magukról véleményezett egészségtudatosságra és környezettudatosságra vonatkozó megállapítások.

A következőkben az előzőekre alapozva, mely szerint inkább az egészségtudatosság jellemzi a minta alapján a vizsgált sokaságot, megvizsgáltuk, hogy az élelmiszer-fogyasztást döntően befolyásoló speciális étrendek milyen arányban jelennek meg a hallgatók esetében. A megkérdezettek kétharmada (69\%) nem követ speciális diétát, saját elhatározásból 17\%, míg valamilyen betegség vagy ételérzékenység miatt $14 \%$-uk étrendje speciális (6. ábra). A vizsgált korosztályból (fiatal felnőttek) adódóan ez nem egy meglepő eredmény, arra viszont rávilágít, hogy a népszerü diétáknak van nagyobb szerepe az élelmiszer-fogyasztásuk során. A betegség vagy ételérzékenység esetében a laktózintolerancia, keresztallergia és a cukorbetegség volt a legjellemzőbb ok. A saját elhatározásból folytatott diéták esetében a fehérjedús, a vega, a vegán és a gluténmentes étrend volt a legjellemzőbb. A válaszadók 34\%-a vegyes étrendet is speciális diétának tartotta. A fehérjedús étrend kiemelkedően magas arányban lett megjelölve, azok közül, akik követnek speciális étrendet, minden harmadik hallgató ezt választja. Ez a ma divatos „sportos” életmóddal hozható összefüggésbe, amely pont a magas fehérjeigény okán nem feltétlenül szolgálja a környezetvédelem érdekeit.

\section{6. ábra: Speciális étrendet követők a DE hallgatóinak körében $(n=500)$}
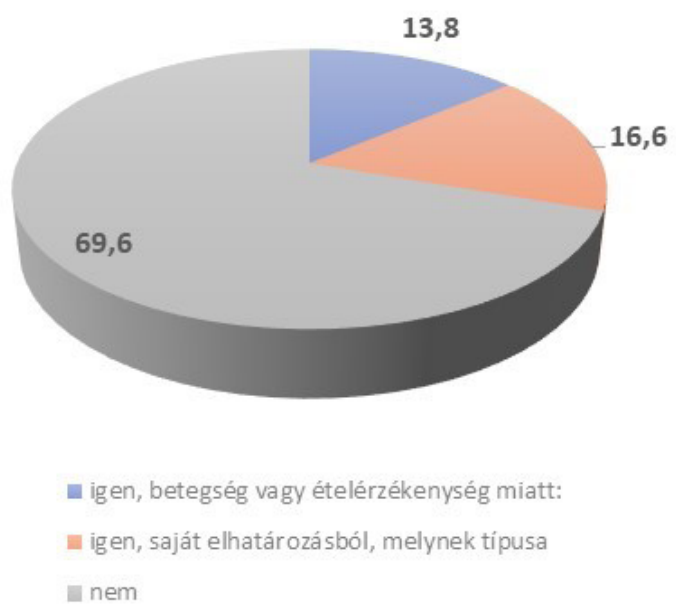

Megjegyzés: A 6. ábra a kérdőiv 16. „Tart-e diétát vagy speciális étrendet?” kérdésére adott válaszok alapján készült. 
A felmérésben résztvevő korosztályról elmondható, hogy jellemzően még nem gondolkodnak az egészségmegőrzésben, a prevencióban, ugyanakkor szívesen követnek sportos életmódot, viszont a testmozgást és a táplálkozást nem társítják az egészségtudatossághoz.

Megvizsgáltuk azt is, hogy az egészségtudatos és a környezettudatos hallgatók preferenciái mennyire egyeznek meg. Megállapítható, hogy mind a magukat környezettudatosnak vallók, mind a magukat egészségtudatosnak tekintő hallgatók az élelmiszer-vásárlási és -fogyasztási döntéseik során a minőséget előrébb sorolják az árral szemben, a környezettudatos hallgatók a helyi termékeket jobban preferálják, mint az egészségtudatos fogyasztók, és a környezettudatos élelmiszer-fogyasztók magasabb átlagértéket rendelnek az egészségtudatossághoz, mint amit megfigyelhetünk fordított helyzetben, vagyis az egészségtudatos fogyasztók kevésbé tartják fontosnak a környezettudatosságot (2. táblázat).

\begin{tabular}{|l|c|c|c|c|c|c|}
\hline & \multicolumn{3}{|c|}{ Egészségtudatos } & \multicolumn{3}{c|}{ Környezettudatos } \\
\hline \multirow{2}{*}{ Ár } & Átlag & Szórás & Medián & Átlag & Szórás & Medián \\
\hline Minöség & 4,11 & 0,85 & 4 & 4,18 & 1,14 & 4 \\
\hline Helyi termékek & 4,20 & 0,64 & 4 & 4,60 & 0,70 & 5 \\
\hline Márka & 3,73 & 1,10 & 4 & 4,30 & 1,16 & 5 \\
\hline Környezettudatosság & 3,31 & 1,05 & 3 & 3,34 & 1,36 & 3 \\
\hline Egészségtudatosság & 3,64 & 0,77 & 4 & 4,62 & 0,53 & 5 \\
\hline
\end{tabular}

Kereszttábla-elemzést és Pearson-féle Chi2-próbát végeztünk el annak megállapítására, hogy a magukat környezettudatosnak vallók csoportja, a speciális diétát követők csoportja és a magukat egészségtudatosnak tekintő és a speciális diétát követők csoportja között van-e szignifikáns kapcsolat. A vizsgálatot $\mathrm{P}<0,005$ szint alatt végeztük el, a minta száma 500 fó volt. Az elvégzett próba alapján megállapítható, hogy a magukat környezettudatosnak tartók esetében nem jellemző a speciális diéta követése, vagyis élelmiszer-fogyasztásukra leginkább a vegyes táplálkozás jellemző $(\mathrm{P}<$ 0,151). Ez alapján levonható az a következtetés, hogy a környezettudatosság nem készteti őket speciális étrend követésére, például kevesebb állati eredetű fehérje fogyasztására. Míg az egészségtudatos élelmiszer-fogyasztóknál már szignifikáns összefüggés $(\mathrm{P}<$ $0,001)$ mutatható ki a speciális diétát követők és a vizsgált csoport között. Az egészségtudatos hallgatók jellemzően a fehérjedús étrendet választják, ami visszavezethető arra, hogy a vizsgált korosztály az egészségtudatosságot a rendszeres testmozgással azonosítja, mely esetben a magasabb fehérjebevitel jelenik meg az étkezési szokásuknál.

\section{KÖVETKEZTETÉSEK, JAVASLATOK}

Az élelmiszer-fogyasztás kapcsán a felmérés alapján megalapítható, hogy a hallgatók az ár tekintetében tekintik leginkább élelmiszer-vásárlásaik során tudatosnak magukat, csak ezt követi egy kis lemaradással a minőség mint befolyásoló tényező. $\mathrm{Az}$ egészségtudatosság inkább jellemzi a hallgatókat, mint a környezettudatosság, vagyis az önérdek dominánsabban jelenik meg, mint a közösségi érdek a döntéseik során. Ezt támasztja alá az is, hogy kevesebb az ismeretük - saját bevallásuk szerint - a környezettudatosságról, mint az egészségtudatosságról. A környezettudatosság tekintetében inkább jellemzi őket az elutasító magatartás, mint az egészségtudatosság esetében. A magukat környezettudatos élelmiszer-fogyasztóknak vallók csoportja fontosnak ítéli meg az egészségtudatosságot, fordított esetben ez nem mondható el.

$\mathrm{A} z$ élelmiszer-fogyasztást befolyásoló speciális étrendek köve- tése csak kevésbé jellemzi a vizsgált sokaságot, a korosztályból adódóan inkább saját elhatározásból, sem mint valamilyen betegség vagy érzékenység miatt változtatnak az étrendjükön. A környezettudatosság és a speciálisétrend-követés között nem találtunk öszszefüggést, azonban az egészségtudatosság és a speciális étrendet követők csoportja között szignifikáns kapcsolat fedezhető fel. Ez alapján az önérdekre ható módon inkább befolyásolható a vizsgált sokaság, így az egészség mint hívó-szó hatékonyabban fejtheti ki a hatását, mint a környezeti aspektusokra való hivatkozás.

\section{5. ÖSSZEFOGLALÁS}

Mind a hazai mind a nemzetközi szakirodalomban egyetértés van abban, hogy az egészségtudatosság és a környezettudatosság együttesen jellemzi a fenntartható élelmiszer-fogyasztást. A vizsgálat jelen esetben a felnövő generáció élelmiszer-fogyasztási szokásainak felmérésére irányult, a mostani 18-25 éves korosztály tekinthető a „közeljövő fogyasztójának”, a vizsgált korcsoportban a felsőoktatási hallgatók esetében elmondható, hogy a fogyasztásaik során, különösen az élelmiszer-fogyasztás területén önálló döntéshozónak tekinthetőek. Ezen életszakaszban kialakuló fogyasztási minták - melyet az oktatásból szerzett információk is befolyásolnak - meghatározóak lehetnek a későbbiekre is.

A felmérésünk alapján megállapítható, hogy a Debreceni Egyetem hallgatói kevésbé ismerik a környezettudatosság kritériumait, mint az egészségtudatosság jellemzőit, inkább tekintik magukat egészségtudatos élelmiszer-fogyasztónak mint környezettudatos élelmiszer-fogyasztónak, s nagyobb arányban utasítják el az élelmiszer-fogyasztás kapcsán a környezeti szempontokat, inkább az önérdek dominál a mások érdekeivel szemben a döntéseiknél. Kiemelendő, hogy a fentiek minden esetben a vélt, saját magukról véleményezett egészségtudatosságra és környezettudatosságra tett megállapítások. A továbbiakban azt szándékozzuk vizsgálni, hogy a vélt és a valós tudatosság között milyen összefüggés fedezhető fel az élelmiszer-fogyasztás tekintetében. 


\section{KÖSZÖNETNYILVÁNÍTÁS}

A publikáció elkészítését az EFOP-3.6.1-16-2016-00022 számú, „Debrecen Venture Catapult Program” címü projekt támogatta. A projekt az Európai Unió támogatásával, az Európai Szociális Alap társfinanszírozásával valósult meg.

\section{IRODALOM}

Ádám, F. (2001). A fenntartható fogyasztás családi és iskolai közösségekben. In N. N. Attila (Szerk.), Bimbó boci bólászása. Budapest: Magyar Környezeti Nevelési Egyesület. Letöltés dátuma: 2019.07.02. forrás: http://mkne.hu/pie/piekonyv2.html

Alsaffar, A. A. (2016). Sustainable diets: the interaction between food industry, nutrition, health and the environment. Food Science and Technology International, 2(22), 102-111. doi: $10.1177 / 1082013215572029$

Brochado, A., Teiga, N. \& Oliveira-Brochado, F. (2017). The ecological conscious consumer behaviour: are the activists different? International Journal of Consumer Studies, 2(41), 138-146. doi: 10.1111/ijcs.12321

De Boer, J., Aiking, H. (2018). Prospects for Pro-Environmental Protein Consumption in europe: Cultural, Culinary, economic and Psychological factors. Appetite, 121, 29-40. doi: 10.1016/j.appet.2017.10.042

Dudás, K. (2010). A tudatos fogyasztás. In: Csépe A. (Szerk.): Új Marketing Világrend. Marketing Oktatók 16. Országos Konferenciája, (pp. 687-699). Budapest: Budapesti Kommunikációs és Üzleti Főiskola

Dudás, K. (2012). A tudatos fogyasztói magatartás dimenziói, különös tekintettel a mások érdekeire fókuszáló felelős fogyasztásra. Marketing E Menedzsment, 46(1-2), 52-63.

Kiss , Á., Dombi , M. \& Szakály, Z. (2019). Az egészség, a környezet és az étkezés kapcsolata - Szakirodalmi áttekintés. Táplálkozásmarketing, 6(1), 3-23. doi: 10.20494/TM/6/1/1

Lázár, E. (2009). Kutatásmódszertan a gyakorlatban az SPSS program használatával. Kolozsvár: Scientia.

Lehota Zs., Lehota J., Komáromi N. \& Illés B. Cs. (2018). $\mathrm{A} z$ élelmiszerfogyasztói információ-ellátottság, a bizalom és a fogyasztói magatartás kapcsolatrendszere. In I. B. Cs. (Szerk.),
Gazdálkodás- és szervezéstudomány: Új kihívások az elméletben és gyakorlatban (pp. 653-661). Gödöllő, Magyarország: Szent István Egyetem.

Macdiarmid, J. I. (2016). Eating like there's no tomorrow: public awareness of the environmental impact of food and reluctance to eat less meat as part of a sustainable diet. Appetite, 96, 487-493. doi: 10.1016/j.appet.2015.10.011

Ruini, L., Ciati, R., Pratesi , C., Marino, M. \& Princiapato, L. (2015). Working toward Healthy and Sustainable Diets: The "Double Pyramid Model". Frontiers in Nutrition, 2, 1-6. doi: $\underline{10.3389 / \text { fnut.2015.00009 }}$

Sajtos L., M. A. (2007). SPSS kutatási és adatelemzési kézikönyv. Budapest: Alinea Kiadó.

Szakály Z., Szigeti O., Polereczki Zs. \& Szente V. (2014). Kapcsolat a személyes értékek, az egészségtudatosság és az élelmiszervásárlói magatartás között. In Lehota J., Berács J. \& Rekettye G. (Szerk.), Tomcsányi Pál akadémikus 90 éves: Az életminőség anyagi- és szellemi igényeinek kielégítése fogyasztási marketing szemlélettel (pp. 129-152). Budapest: MTA Agrár-közgazdasági Bizottság Agrármarketing Albizottság.

Szűcs, R. S. (2019). Az élelmiszerpazarlás és a fogyasztói tudatosság kapcsolata. Táplálkozásmarketing, 6(1), 69-80. doi: $10.20494 / \mathrm{tm} / 6 / 1 / 5$

Totth, G. (2018). A fogyasztói magatartás fogalma. In Vámosi K. (Szerk.), Marketing vezérelt értékelemzés (pp. 31-40). Budapest: Budapesti Gazdasági Egyetem.

Törőcsik, M. (2003). Fogyasztói magatartás trendek - Új fogyasztói csoportok. Budapest: KJK Kerszöv. Jogi és Üzleti Kiadó.

Törőcsik, M. (2014). Az ételfogyasztás megatrend kapcsolódásai. Táplálkozásmarketing, 1(1-2), 19-27. doi: 10.20494/ $\mathrm{tm} / 1 / 1-2 / 2$

Tudatos Vásárlók Egyesülete. (2017). Tudatos Vásárló Piaci Jelentés. Letöltés dátuma: 2019.01.23. forrás: http://issuu.com/ tudatosvasarlok/docs/tudatos_vasarlo_piaci_jelentes

Zabkar, V. \& Hosta, M. (2013). Willingness to act and environmentally conscious consumer behaviour: can prosocial status perceptions help overcome the gap? International Journal of Consumer Studies, 3(37), 257-264. doi: 10.1111/j.1470$\underline{6431.2012 .01134 . x}$ 